\title{
Corrigendum: Cyberweapons: an emerging global governance architecture
}

Tim Stevens

Correction to: Palgrave Communications (2017) 3, Article number: 16102. doi: 10.1057/palcomms.2016.102; Published 10 January 2017; Updated 19 January 2017

Previously the volume number given for the citation in the Additional Information section of this paper was incorrectly given as volume 2. This has now been corrected to volume 3. The year in the Additional Information section was incorrectly given as 2016. This has now been corrected to 2017.

The article has been corrected online.

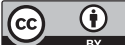

This work is licensed under a Creative Commons Attribution 4.0 International License. The images or other third party material in this article are included in the article's Creative Commons license, unless indicated otherwise in the credit line; if the material is not included under the Creative Commons license, users will need to obtain permission from the license holder to reproduce the material. To view a copy of this license, visit http://creativecommons.org/licenses/by/4.0/ 